\title{
RECONNECTING SAMBUNGAN RUMAH (SR) PADA GARDU 079 \\ SOVIA UNTUK MENGURANGI LOSSES DI PT PLN (PERSERO) RAYON BUKITTINGGI \\ (MENGGUNAKAN APLIKASI JARINGAN SYARAF TIRUAN) oleh \\ Junaidi Asrul, S.ST, MT ${ }^{1}$., Firmansyah, ST,MT², \\ Staf Pengajar Jurusan Teknik Elektro Politeknik Negeri Padang-PNP ${ }^{1,2}$ \\ E-mail : junaidi_8189@yahoo.co.id
}

\begin{abstract}
ABSTRAK
Dengan melakukan reconnecting dapat mengatasi rugi-rugi energi. Pada titik sambungan percabangan disambungan rumah sampai ke $k W h$ meter digantikan dengan compression Connector. Terminal pada kWh meter sering terjadi loss kontak. Dengan sering terjadinya loss kontak, maka terminal pada $\mathrm{kWh}$ meter digantikan dengan menggunakan joint sleeve bimetal.

Besarnya rugi jaringan disebabkan oleh penggunaan tap connector pada titik sambungan dan terminal pada kWh meter pelanggan. Digardu 079 Sovia area kerja PT. PLN (Persero) rayon Bukittinggi mengalami rugi $k W h$ salur pada bulan desember 2013 januari 2014 sebesar $13 \%$. Setelah dilakukan reconnecting, rugi $k W h$ salur menurun menjadi 4,48\% pada bulan Mei 2014. Dengan menggunakan jaringan Syaraf Tiruan, dapat dilihat kinerja untuk rugi $\mathrm{kWh}$ salur setelah dilakukan reconnecting lebih baik.
\end{abstract}

Kata Kunci : Reconnecting jaringan Tegangan Rendah, Compression Connector (CCO), Tap Connentor, Joint Sleeve Bimetal, Rugi jaringan (Rugi kWh Salur)

\section{PENDAHULUAN}

Rugi-rugi energi merupakan suatu kondisi atau keadaan dimana jumlah energi yang disalurkan tidak sama dengan energi yang diterima pada sisi penerimaan.Terjadinya rugi-rugi energi ini dapat disebabkan oleh berbagai faktor, seperti jauhnya daerah penyaluran tenaga listrik dari sumber/suplai, drop tegangan, ketidakseimbangan beban, umur peralatan, diameter penghantar dan lain- lain.

Rugi-rugi energi menyeluruh tetapi hanya bisa diminimalkan. Loss situation di dalam jaringan distribusi tenaga listrik adalah suatu kondisi atau keadaan dimana suatu sistem distribusi di dalam pendistribusian tenaga listriknya mengalami rugi-rugi energi yang tinggi.

Kecendrungan meningkatnya kebutuhan akan sarana sambung kabel jaringan tegangan rendah ke sambungan rumah, seiring dengan adanya peningkatan ekspansi maupun kerusakan jaringan kabel tembaga yang diakibatkan susut teknis, maka muncul kendala dengan adanya jenis sarana sambungan kabel.

Jarak gardu ke konsumen terlalu jauh, penampang kabel terlalu kecil, dan titik sambung merupakan penyebab susut teknis. Cara pengerjaan titik sambung yang tidak sesuai dengan Standard Operating Procedure (SOP) dan kualitas titik sambung yang kurang baik merupakan penyebab dari susut teknis. Maka di lakukan penggantian titik sambung padaSambungan Rumah (SR) dari Tap Konektor menjadi Compression Connector (CCO). Sedangkan pada kWh meter terminal yang digunakan sebagai titik sambung di ganti dengan Joint Sleeve Bimetal. Dengan menggunakan Compression Connector (CCO) d a n Joint Sleeve Bimetal ini diharapkan dapat mengurangi rugi-rugi tegangan dititik sambung dalam upaya penurunan rugi jaringan PT PLN (Persero) Rayon Bukittinggi, sehingga dapat memberikan kontribusi dalam rangka penekanan susut 
kWh yang berdampak bagi peningkatan efisiensi dan kinerjanya. Dari penjelasan tersebut maka penulis akan membahas tentang "Reconnecting Sambungan Rumah (SR) Pada Gardu 079 Sovia untuk Mengurangi Losses (kWh salur) di PT.PLN (Persero) Rayon Bukittinggi (Menggunakan Aplikasi Jaringan Syaraf Tiruan)".

\section{TUJUAN PENELITIAN}

Adapun tujuan penelitian adalah :

1. Menghitung losses (kWh salur) pada sambungan rumah sebelum dilakukan reconnecting dan menghitung losses (kWh salur) pada sambungan rumah setelah dilakukan reconnecting.

3. Mengetahui pengaruh dan kinerja dengan dilakukannya reconnecting sambungan rumah.

4. Menggunakan metoda Jaringan Syaraf Tiruan untuk melihat kinerja dari reconnecting terhadap losses $(\mathrm{kWh}$ salur).

\section{METODE PENELITIAN}

Dalam pembahasan penelitian ini dilakukan beberapa metoda pembahasan antara lain:

a. Studi lapangan

Pengumpulan data dilakukan dengan cara melakukan survey lansung kelapangan dimana penulis dapat mencatat data-data yang ada dilapangan. Selain itu penulis juga melakukan wawancara kepada pengawas lapangan Bagian Distribusi PT. PLN (Persero) Rayon Bukittinggi serta pelaksanaan pekerja yaitu berlokasi di Gardu 079 Sovia.

b. Studi Literatur

Pada metoda ini dilakukan pembelajaran terhadap berbagai literatur yang menunjang dan berkaitan dengan masalah-masalah mengenai pemasangan material Compression Conector (CCO), Joint Sleeve Bimetal dan teori-teori yang menunjang terhadap permasalahan yang dibahas c. Menggunakan metoda Jaringan Syaraf Tiruan untuk melihat kinerja reconnecting sambungan rumah sebelum dan sesudah pengerjaan.

\section{TINJAUAN PUSTAKA}

\section{Jenis-Jenis Konstruksi Sambungan Rumah}

Berdasarkan jenis kontruksi sambungan

Tenaga Listrik ada beberapa Tipe :

1. Konstruksi Sambungan Tenaga Listrik tipe A.

2. Konstruksi Sambungan Tenaga Listrik Tipe B.

3. Konstruksi Sambungan Tenaga Listrik Tipe C (Pada SPLN No. 56-1984 disebut Tipe D)

4. Konstruksi Sambungan Tenaga Listrik Tipe D ( Pada SPLN No. 56 -1984 disebut Tipe F).

5. Konstruksi Sambungan Tenaga Listrik Tipe E (Pada SPLN No. 56 1984 disebut Tipe UG).

6. Konstruksi Sambungan Tenaga Listrik Tipe F (APP terpusat pada tiang)

7. Konstruksi Sambungan Tenaga Listrik Tipe G ( APP tersebut pada bangunan).

\section{Joint Sleeve Bimetal}

Joint sleeve bimetal digunakan sebelum terminasi kabel sambungan pelayanan pada terminal meter $\mathrm{kWh}$, mengingat inti kabel terbuat dari alumunium dan terminal $\mathrm{kWh}$ terbuat dari tembaga.

\section{Sadapan dan Terminasi (Connector Tap)}

Sadapan SLP pada saluran udara memakai hydraulic press tap connector (tipe $\mathrm{H}$ atau tipe $\mathrm{O}$ press connector) atau hand press connector untuk berbagai macam ukuran penampang jenis piercing. Jenisnya dapat berupa dari logam $\mathrm{Al}$ atau $\mathrm{Cu}$, penggunaan disesuaikan dengan jenis logam penghantar saluran udaranya. Terminal pada PHB memakai terminal lug 
(sepatu kabel atau kabel skun) jenis $\mathrm{Al} \mathrm{Cu}$ atau bimetal.

\section{Connector.}

Untuk menyambung antara dua penghantar, secara umum dipakai material penyambung yang disebut Connector. Secara prinsip, fungsi dan tujuan utama dari konektor ini adalah menyatukan dua penghantar sedemikian rupa sehingga tahanan kontak penyambungan itu menjadi sangat kecil (kalau perlu NOL).

Pada sambungan JUTM, berbagai model konektor juga dipakai, antara lain; parallel groove, type $\mathrm{H}$, joint sleeve, dan yang terakhir adalah generasi untuk PDKB (Pekerjaan Dalam Keadaan Bertegangan) yaitu LLC (Live Line Connector).

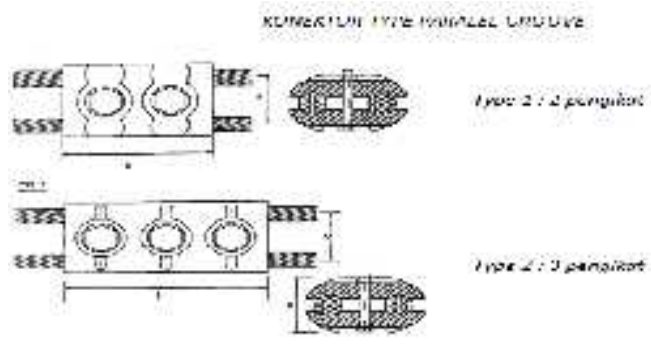

Gambar 2.Connector Type ParalelGroove

Gambar 2 merupakan jenis konektor parallel-groove yang terdiri dari type 2 pengikat dan 3 pengikat. Berdasarkan prinsip konektor yang di definisikan di atas, maka type 3 pengikat lebih bagus dari type 2 pengikat, tentunya karena pada 3 pengikat lebih banyak luas permukaan kontak yang bersinggungan/menyatu antara dua kawat/penghantar.

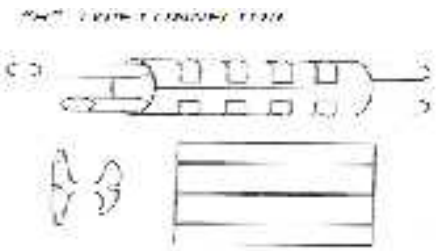

Gambar 3.Connector tipe $\mathrm{H}$

Untuk penyambung JTM yang ditarik (antar tiang), maka conektor yang dipakai seharusnya model "join sleeve" (gambar 4). Join sleeve adalah konektor yang berupa selonsong dan padanya ujungujung kawat dimasukkan kemudian dipress dengan alat press kabel.Untuk tap-konektor (tanpa tarikan), bisa memakai model paralelgroove atau type $\mathrm{H}$.

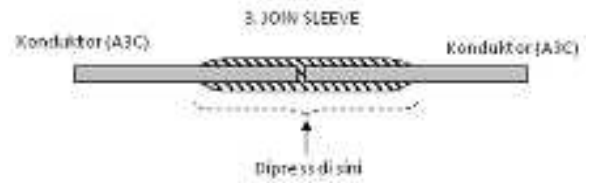

Gambar 4.Joint Sleeve Bimetal

Diantara ketiga konektor tersebut join sleeve adalah yang paling bagus, baik sifat mekaniknya (tarikan) maupun sifat elektrisnya (kontak antara 2 penghantar yang di sambung memungkinkan Kemampuan Daya Hantar (KHA konektor $=\mathrm{KHA}$ kawat$/$ penghantar $)$. Terlihat juga dalam gambar 10 bahwa paralel - groove kualitas kontak kelihatannya kurang bagus (pakai mur - baut).

Untuk sambungan pada JTR dan SR, sekarang menggunakan connector jenis terbaru yaitu Compression Connector (CCO). Konektor jenis CCO ini digunakan untuk penyambungan kabel alumunium pada jaringan konduktor alumunium dengan menggunakan sistem press.

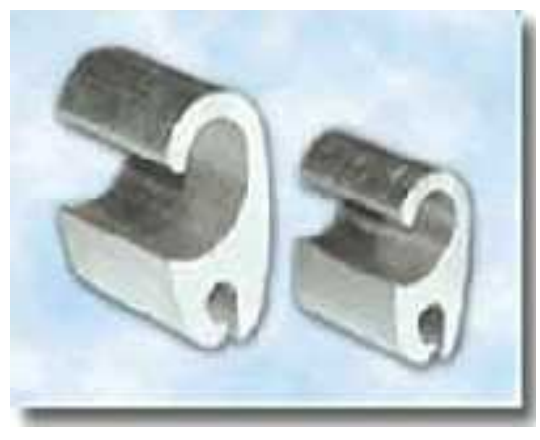

Gambar 5.Compression Connector (CCO)

\section{Perhitungan Rugi Rugi kWh Salur}

Untuk mengetahui rugi $\mathrm{kWh}$ salur yang terjadi tiap bulannya, harus dilakukan pengukuran stand meter pada $\mathrm{kWh}$ induk yag dipasang pada gardu dan stand meter $\mathrm{kWh}$ meter pelanggan. Rumus 
untuk mendapatkan $\mathrm{kWh}$ salur tiap bulannya yaitu sebagai berikut:

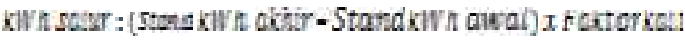

(1)

Setelah mendapatkan besarnya kWh yang disalurkan dari gardu ke pelanggan, maka akan dilakukan perhitungan untuk mandapatkan besarnya selisih $\mathrm{kWh}$ salur yang terjadi pada gardu tersebut, rumus yang digunakan yaitu:

Selisin KWh salur:

kWh Salur - Jumlah kWh Pelan ggan ......(2)

Untuk mendapatkan persentase rugi $\mathrm{kWh}$ salur, hasil perhitungan $\mathrm{kWh}$ salur dan selisih $\mathrm{kWh}$ salur dimasukan kedalam rumus:

$$
\begin{aligned}
& \text { Persentase ruyi } k W h: \\
& =\left(\frac{\text { SelisinkWh }}{k W h \text { Salur }}\right) \times 100 \ldots \ldots \ldots \ldots
\end{aligned}
$$

\section{Perhitungan Jatuh Tegangan}

Dengan menghitung jatuh tegangan, selain dipengerahui oleh panjang, luas penampang, dan tahanan jenis penghantar maka, rugi tegangan pada jaringan juga ditentukan oleh arus yang mengalir pada penghantar dan daya yang diterima oleh beban serta factor kerjanya. Dan rumus untuk menghitung jatuh tegangan adalah : Untuk Tegangan AC 1 Phasa

$$
\Delta v=\frac{2 \cdot 1 \cdot \ell \cdot \cos \emptyset}{\operatorname{six} A}
$$

Untuk Tegangan AC 3 Phasa

$$
\Delta v=\frac{\sqrt{3} \cdot l \cdot l \cdot \cos \emptyset v o l t}{S x A}
$$

Dimana :

$$
\begin{aligned}
\mathrm{I}= & \text { Arus yang mengalir pada gambar } \\
& \text { pada penghantar (Ampere }) \\
\mathrm{V}= & \text { Rugi tegangan } \\
\ell \quad= & \text { Panjang penghantar }(\mathrm{km}) \\
\mathrm{A} \quad= & \text { Luas penampang penghantar } \\
& \left(\mathrm{mm}^{2}\right) \\
\mathrm{Vs}= & \text { Tegangan sumber ( volt }) \\
\mathrm{Cos} \emptyset= & \text { Faktor kerja } \\
\mathrm{S} \quad & =\text { Daya beban }
\end{aligned}
$$

Untuk menentukan harga daya-antar pada suatu penghantar sangat dipengaruhi oleh jenis penghantar yang dipakai. Untuk lebih memudahkan kita dalam menentukan besarnya daya-antar arus yang dipergunakan pada suhu suatu jaringan, bahan dan tahanan jenis dapat di lihat daftar table.

Rumus untuk menghitung jatuh tegangan dengan menggunakan metode pada beban :

$$
\Delta v=\frac{100 \cdot p \cdot \varepsilon \cdot(k \cos \theta+x \sin \theta)}{V^{2}}
$$

atau

$$
\begin{aligned}
& \Delta v=\frac{100 \operatorname{s} \& \cdot(\kappa \cos \theta+x \sin \theta)}{V^{2}} . \\
& \mathrm{v}=\text { Jatuh tegangan }(\%)
\end{aligned}
$$

Dimana :

$\mathrm{P}=$ Beban $(\mathrm{kVA})$

$\ell=$ Panjang koduktor $(\mathrm{km})$

$\mathrm{R}=$ Tahanan konduktor $(\mathrm{ohm} / \mathrm{km})$

$\mathrm{X}=$ Reaktansi konduktor $(\mathrm{ohm} / \mathrm{km})$

$\mathrm{V}=$ Tegangan fasa ke fasa ( Volt )

$\mathrm{S}=$ Daya $(\mathrm{kVA})$

Beberapa faktor yang menyebabkan terjadinya jatuh tegangan yaitu :

1. Besar beban terpasang

2. Daya beban

3. Impendansi jaringan, dan

4. Pengaruh cara penyambungan

\section{Rugi Energi Listrik}

Perhitungan rugi energi listrik adalah perhitungan sederhana beban netral tak seimbang dengan beban daya tak seimbang. Dengan rumus untuk menghitung daya beban tak seimbang sebagai berikut :

$d p=l r^{2} \times K \times L+l s^{2} \times k \times l+$

$$
I t^{2} \times R \times L
$$

Dimana :

$$
\begin{array}{ll}
\mathrm{dp} & =\begin{array}{l}
\text { Daya Beban Yang Hilang } \\
\end{array} \\
\mathrm{Ir}^{2} \mathrm{Is}^{2}, \mathrm{It}^{2} & =\text { Phase } \\
\mathrm{R} \& \mathrm{~L} & =\text { Daya Beban Tak Seimbang }
\end{array}
$$

\section{Jaringan Syaraf Tiruan (JST)}

\section{Pengertian Jaringan Syaraf Tiruan} (JST)

Jaringan Syaraf Tiruan adalah paradigma pemrosesan suatu informasi yang terinspirasi oleh sistim sel syaraf biologi, sama seperti otak yang memproses suatu informasi. Elemen 
mendasar dari paradigma tersebut adalah struktur yang baru dari sistim pemrosesan informasi. Jaringan Syaraf Tiruan, seperti manusia, belajar dari suatu contoh. Jaringan Syaraf Tiruan dibentuk untuk memecahkan suatu masalah tertentu seperti pengenalan pola atau klasifikasi karena proses pembelajaran [Smith,2003]

Jaringan Syaraf Tiruan berkembang secara pesat pada beberapa tahun terakhir. Jaringan Syaraf Tiruan telah dikembangkan sebelum adanya suatu komputer konvensional yang canggih dan terus berkembang walaupun pernah mengalami masa vakum selama beberapa tahun.

\section{Perbandingan Jaringan Syaraf Tiruan dengan Konvensional}

Jaringan Syaraf Tiruan memiliki pendekatan yang berbeda untuk memecahkan masalah bila dibandingkan dengan sebuah komputer konvensional. Umumnya komputer konvensional menggunakan pendekatan algoritma (komputer konvensional menjalankan sekumpulan perintah untuk memecahkan masalah). Jika suatu perintah tidak diketahui oleh komputer konvensional maka komputer konvensional tidak dapat memecahkan masalah yang ada. Sangat penting mengetahui bagaimana memecahkan suatu masalah pada komputer konvensional dimana komputer konvensional akan sangat bermanfaat jika dapat melakukan sesuatu dimana pengguna belum mengatahui bagaimana melakukannya.

Jaringan Syaraf Tiruan dan suatu algoritma komputer konvensional tidak saling bersaing namun saling melengkapi satu sama lain. Pada suatu kegiatan yang besar, sistim yang diperlukan biasanya menggunakan kombinasi antara keduanya (biasanya sebuah komputer konvensional digunakan untuk mengontrol Jaringan Syaraf Tiruan untuk menghasilkan efisiensi yang maksimal. Jaringan Syaraf Tiruan tidak memberikan suatu keajaiban tetapi jika digunakan secara tepat akan menghasilkan suatu hasil yang luar biasa.

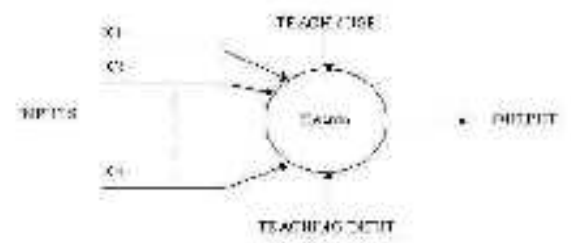

Gambar 9. Sebuah Sel Syaraf Sederhana

\section{Konsep Dasar Jaringan Syaraf Tiruan}

Mengadopsi esensi dasar dari system syaraf biologi, syaraf tiruan digambarkan sebagai berikut : Menerima input atau masukan (baik dari data yang dimasukkan atau dari output sel syaraf pada jaringan syaraf. Setiap input datang melalui suatu koneksi atau hubungan yang mempunyai sebuah bobot (weight). Setiap sel syaraf mempunyai sebuah nilai ambang. Jumlah bobot dari input dan dikurangi dengan nilai ambang kemudian akan mendapatkan suatu aktivasi dari sel syaraf (Post Synaptic Potential dari sel syaraf). Signal aktivasi kemudian menjadi fungsi aktivasi / fungsi transfer untuk menghasilkan output dari sel syaraf.

Biasanya tahapan fungsi jarang digunakan dalan Jaringan Syaraf Tiruan. Fungsi aktivasi (f(.)) dapat dilihat pada Gambar 10

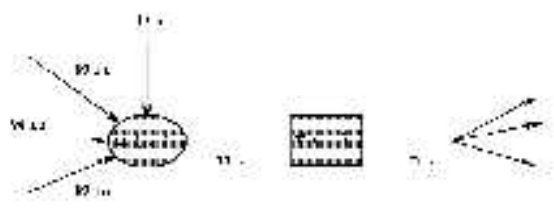

Gambar 10. Fungsi Aktifasi

Bagaimana sel syaraf saling berhubungan? Jika suatu jaringan ingin digunakan untuk berbagai keperluan maka harus memiliki input (akan membawa nilai dari suatu variabel dari luar) dan output (dari prediksi atau signal kontrol). Input dan output sesuai 
dengan sensor dan syaraf motorik seperti signal datang dari mata kemudian diteruskan ke tangan, Dalam hal ini terdapat sel syaraf atau neuron pada lapisan tersembunyi berperan pada jaringan ini. Input, lapisan tersembunyi dan output sel syaraf diperlukan untuk saling terhubung satu sama lain. Berdasarkan dari arsitektur (pola koneksi), Jaringan Syaraf Tiruan dapat dibagi kedalam dua kategori.

\section{Struktur Feed forward}

Sebuah jaringan yang sederhana mempunyai struktur feed forward dimana signal bergerak dari input kemudian melewati lapisan tersembunyi dan akhirnya mencapai unit output (mempunyai struktur perilaku yang stabil). Tipe jaringan feed forward mempunyai sel syaraf yang tersusun dari beberapa lapisan. Lapisan input bukan merupakan sel syaraf. Lapisan ini hanya memberi pelayanan dengan mengenalkan suatu nilai dari suatu variabel. Lapisan tersembunyi dan lapisan output sel syaraf terhubung satu sama lain dengan lapisan sebelumnya. Kemungkinan yang timbul adalah adanya hubungan dengan beberapa unit dari lapisan sebelumnya atau terhubung semuanya dengan baik.

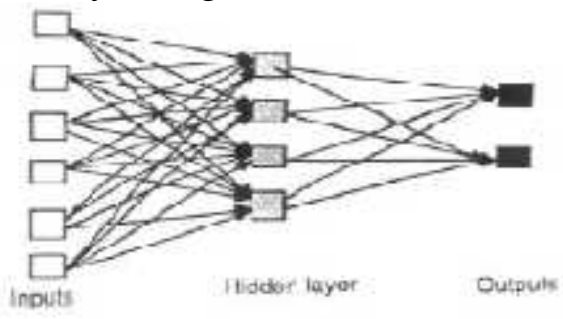

Gambar 11. Jaringan Syaraf Tiruan Feed forward

Yang termasuk dalam struktur feed forward :
a) Single-layer perceptron
b) Multilayer perceptron
c) Radial-basis function networks
d) Higher-order networks

e) Polynomial learning networks

\section{Struktur Recurrent (Feed back)}

Jika suatu jaringan berulang (mempunyai koneksi kembali dari output ke input) akan menimbulkan ketidakstabilan dan akan menghasilkan dinamika yang sangat kompleks. Jaringan yang berulang sangat menarik untuk diteliti dalam Jaringan Syaraf Tiruan, namun sejauh ini struktur feed forward sangat berguna untuk memecahkan masalah. Yang termasuk dalam struktur recurrent (feed back) :

a) Competitive networks

b) Self-organizing maps

c) Hopfield networks

d) Adaptive-resonanse theory models

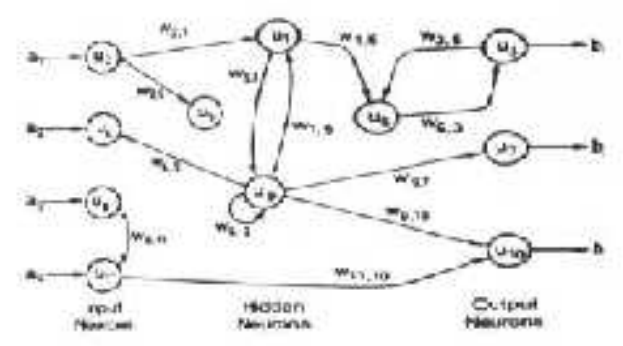

Gambar 12. Jaringan Syaraf Tiruan Feed Back

Ketika sebuah Jaringan Syaraf digunakan. Input dari nilai suatu variabel ditempatkan dalam suatu input unit dan kemudian unit lapisan tersembunyi dan lapisan output menjalankannya. Setiap lapisan tersebut menghitung nilai aktivasi dengan mengambil jumlah bobot output dari setiap unit dari lapisan sebelumnya dan kemudian dikurangi dengan nilai ambang. Nilai aktifasi kemudian melalui fungsi aktifasi untuk menghasilkan output dari sel syaraf. Ketika semua unit pada Jaringan Syaraf telah dijalankan maka aksi dari lapisan output merupakan output dari seluruh jaringan syaraf.

\section{Lapisan pada Jaringan Syaraf Tiruan}

Jaringan Syaraf Tiruan biasanya mempunyai 3 group atau lapisan yaitu unit-unit lapisan input yang terhubung 
dengan lapisan tersembunyi yang selanjutnya terhubung dengan lapisan output.

a) Aktifitas unit-unit lapisan input menunjukkan informasi dasar yang kemudian digunakan dalam Jaringan Syaraf Tiruan.

b) Aktifitas setiap unit-unit lapisan tersembunyi ditentukan oleh aktifitas dari unit-unit input dan bobot dari koneksi antara unit-unit input dan unit-unit lapisan tersembunyi

c) Karakteristik dari unit-unit output tergantung dari aktifitas unit-unit lapisan tersembunyi dan bobot antara unit-unit lapisan tersembunyi dan unit-unit output

\section{Perceptron}

Perceptron termasuk kedalam salah satu bentuk Jaringan Syaraf Tiruan yang sederhana. Perceptron biasanya digunakan untuk mengklasifikasikan suatu tipe pola tertentu yang sering dikenal dengan istilah pemisahan secara linear. Pada dasarnya perceptron pada Jaringan Syaraf dengan satu lapisan memiliki bobot yang bisa diatur dan suatu nilai ambang. Algoritma yang digunakan oleh aturan perceptron ini akan mengatur parameter-parameter bebasnya melalui proses pembelajaran. Fungsi aktivasi dibuat sedemikian rupa sehingga terjadi pembatasan antara daerah positif dan daerah negatif.

\section{Arsitektur Backpropagation}

Di dalam jaringan propagasi balik, setiap unit yang berada di lapisan input terhubung dengan setiap unit yang ada pada lapisan tersembunyi. Hal serupa pula berlaku pada lapisan tersembunyi. Setiap unit yang ada pada lapisan tersmbunyi terhubung dengan setiap unit yang ada di lapisan output.

Jaringan saraf tiruan propagasi balik terdiri dari banyak lapisan (Multi Layer Network):
1. Lapisan input (1 buah). Lapisan input terdiri dari neuron-neuron atau unitunit input, mulai dari unit input 1 sampai unit input $\mathrm{n}$.

2. Lapisan tersembunyi (minimal 1). Lapisan tersembunyi terdiri dari unitunit tersembunyi mulai dari unit tersembuyi 1 sampai unit tersembunyi p.

3. lapisan output (1 buah). Lapisan output terdiri dari unit-unit output mulai dari unit output 1 sampai unit output $m$. n, m, p. Struktur Jaringan Syaraf Tiruan multi layer dapat dilihat Gambar berikut:

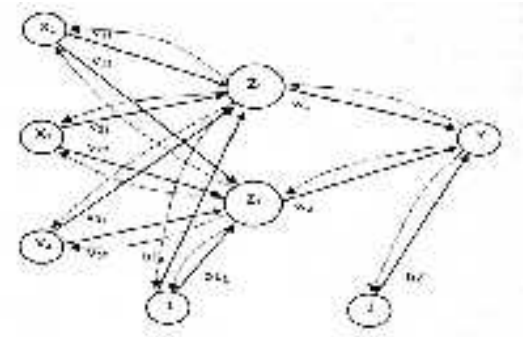

Gambar 13. Struktur Jaringan Syaraf Tiruan Multi layer

Seperti yang diperlihatkan pada gambar 13, bahwa jaringan Backpropagation terdiri dari 3 sel neuron pada lapisan input sedangkan pada lapisan tersembunyi terdapat 2 sel neuron yaitu serta 1 sel neuron pada lapisan output yaitu y. Nilai bias yang diberikan pada lapisan tersembunyi bertujuan untuk mengolah data input ditambah bobot yang masuk ke dalam sel-sel pada lapisan tersembunyi dengan bantuan fungsi aktifasi. Begitupula dengan nilai bias yang diberikan pada lapisan keluaran adalah untuk mengolah data yang berasal dari keluaran sel pada lapisan tersembunyi ditambah bobot yang masuk kedalam lapisan keluaran dengan bantuan fungsi aktifasi. 321dan $\mathrm{x}$ $\mathrm{x}, \mathrm{x} 21 \mathrm{z}$ dan z1b ijv $1 \mathrm{~b}$ ijw

Algoritma Backpropagation adalah sebagai berikut :

1. Inisialisasi bobot (random yang kecil, $-0.5 \mathrm{~s} / \mathrm{d} 0.5$ atau $-1 \mathrm{~s} / \mathrm{d} 1$ ). 
2. Tetapkan maksimum epoch, target error dan learning rate $(\alpha)$

3. Inisialisasi: Epoch $=0, \mathrm{MSE}=1$

4. Berikan harga-harga masukan dan keluaran target yang menjadi paket pelatihan.

\section{HASIL DAN PEMBAHASAN}

Dalam pembahasan penelitian ini dilakukan Pencatatan stan kWh sebelum pemeliharaan dilaksanakan pada awal bulan Desember 2013 sampai dengan awal bulan Februari 2014. Pencatatan dilakukan di $\mathrm{kWh}$ meter induk yang terdapat pada gardu distribusi Sovia dan kWh meter pelanggan yang termasuk kedalam jaringan gardu Sovia. Hasil pencatatan stand $\mathrm{kWh}$ meter induk pada gardu Sovia dapat dilihat pada table 5 berikut :

\section{Tabel 5. Data pencatatan Stand kWh}

Meter Induk sebelum reconnecting

\begin{tabular}{|c|c|c|}
\hline Bulan & $\begin{array}{c}\mathrm{kWh} \text { Induk } \\
(\mathrm{kWh})\end{array}$ & $\begin{array}{c}\text { CT } \\
\text { Terpasang } \\
\text { (Faktor } \\
\text { Kali) }\end{array}$ \\
\hline Desember & 385 & \multirow{2}{*}{ 250/5 A (50) } \\
\hline Januari & 1365 & \\
\hline Februari & 2396 & \\
\hline
\end{tabular}

Sumber : PT.PLN (Persero) Rayon Bukittinggi

Setelah mendapatkan berapa besar $\mathrm{kWh}$ salur tiap bulannya, maka selanjutnya dilakukan perhitungan untuk melihat selisih $\mathrm{kWh}$ yang disalurkan dengan $\mathrm{kWh}$ yang diterima oleh pelanggan. Data total $\mathrm{kWh}$ pelanggan setiap bulannya dapat dilihat pada tabel 6. Untuk mendapatkan besarnya selisih $\mathrm{kWh}$, maka dilakukan perhitungan dari Bulan Desember 2013 sampai Februari 2014, maka hasil perhitungannya sebagai berikut:

Tabel 6. Data pencatatan Stand $\mathrm{kWh}$ Meter Pelanggan sebelum reconnecting

\begin{tabular}{|c|c|c|}
\hline Bulan & $\begin{array}{c}\text { Jumlah } \\
\text { Pelanggan }\end{array}$ & $\begin{array}{c}\text { Total kWh } \\
\text { Pelanggan } \\
(\mathrm{kWh})\end{array}$ \\
\hline Desember 2013 & 145 & 38045 \\
\hline
\end{tabular}

\begin{tabular}{|c|c|c|}
\hline Januari 2014 & 145 & 39980 \\
\hline Februari 2014 & 145 & 40513 \\
\hline
\end{tabular}

Setelah dilakukan perhitungan, maka dapat dilihat pada tabel 7 besarnya $\mathrm{kWh}$ yang disalurkan setiap bulannya, selisih $\mathrm{kWh}$ yang disalurkan tiap bulannya dan persentase losses yang terjadi setiap bulannya.

Tabel 7. Data Hasil perhitungan sebelum reconnecting

\begin{tabular}{|c|c|c|c|}
\hline Bulan & $\begin{array}{c}\text { kWh } \\
\text { Salur } \\
(\mathrm{kWh})\end{array}$ & $\begin{array}{c}\text { Selisih kWh } \\
\text { Salur }(\mathrm{kWh})\end{array}$ & $\begin{array}{c}\text { Losses } \\
(\%)\end{array}$ \\
\hline $\begin{array}{c}\text { Desember } \\
2013\end{array}$ & 44100 & 6055 & 13.73 \\
\hline $\begin{array}{c}\text { Januari } \\
2014\end{array}$ & 46395 & 6415 & 13.83 \\
\hline
\end{tabular}

Jadi dari hasil pengumpulan data dan hasil perhitungan yang dilakukan sebelum dilakukan reconnecting maka PT. PLN mengalami kerugian yang cukup besar setiap bulannya akibat dari besarnyya losses dari Sambungan rumah yang di pasang sebelumnya.

Pencatatan kWh meter setelah dilakukan pemeliharan dilaksanakan pada awal bulan Februari 2014 sampai dengan awal bulan Juni 2014. Pencatatan dilakukan di $\mathrm{kWh}$ meter induk yang terdapat pada gardu distribusi Sovia dan $\mathrm{kWh}$ meter pelanggan yang termasuk kedalam jaringan gardu distribusi Sovia. Hasil pencatatan stand $\mathrm{kWh}$ meter induk pada gardu distribusi Sovia dapat dilihat pada table 8 berikut :

Tabel 8.Data Pencatatan Stand kWh Meter Induk setelah reconnecting

\begin{tabular}{|c|c|c|}
\hline Bulan & $\begin{array}{c}\mathrm{kWh} \\
\text { Indu } \\
\mathrm{k}\end{array}$ & $\begin{array}{l}\text { CT Terpasang } \\
\text { (Faktor Kali) }\end{array}$ \\
\hline Februari & 2396 & \multirow{5}{*}{$250 / 5$ A (50) } \\
\hline Maret & 3312 & \\
\hline April & 4338 & \\
\hline Mei & 5373 & \\
\hline Juni & 6448 & \\
\hline
\end{tabular}


Dari data hasil pencatatan stand $\mathrm{kWh}$ meter induk tersebut, maka selanjutnya dapat dilakukan perhitungan untuk menentukan besarnya kWh yang disalurkan dari gardu ke pelanggan selama satu bulan. Untuk mendapatkan besarnya $\mathrm{kWh}$ salur jaringan setiap bulannya dilakukan perhitungan berikut:

Besar kWh salur jaringan untuk bulan Februari 2014:

$$
\begin{gathered}
=(\text { Stand } k \text { Wh akhir }- \text { Stand } k \text { Wh awal }) \times \text { Faktor kad } \\
=(3312-2396) \times 50
\end{gathered}
$$$$
=45800 \mathrm{kWh}
$$

Begitu juga perhitungan pada Bulan Maret, April, Mei dan juni 2014, maka hasil perhitungan tersebut dapat dilihat pada tabel dibawah ini :

Tabel 9. Data pencatatan Stand kWh Meter Pelanggan Setelah reconnecting

\begin{tabular}{|c|c|c|}
\hline Bulan & $\begin{array}{c}\text { Jumlah } \\
\text { Pelanggan }\end{array}$ & $\begin{array}{c}\text { Total kWh } \\
\text { Pelanggan } \\
(\mathrm{kWh})\end{array}$ \\
\hline Februari & 145 & 40513 \\
\hline Maret & 145 & 44563 \\
\hline April & 145 & 44615 \\
\hline Mei & 145 & 46210 \\
\hline Juni & 145 & 42299 \\
\hline
\end{tabular}

Setelah mendapatkan berapa besar $\mathrm{kWh}$ salur tiap bulannya, maka selanjutnya dilakukan perhitungan untuk melihat selisih $\mathrm{kWh}$ yang disalurkan dengan $\mathrm{kWh}$ yang diterima oleh pelanggan. Data total $\mathrm{kWh}$ pelanggan setiap bulannya dapat dilihat pada tabel 9. Untuk mendapatkan besarnya selisih $\mathrm{kWh}$, maka dilakukan perhitungan sebagai berikut:

Selisih kWh bulan Februari 2014:

$$
\begin{aligned}
& =k W h \text { Salur }- \text { Jumlah } k W h \text { Pelanggan } \\
& =41220-40513 \\
& =707 \mathrm{kWh}
\end{aligned}
$$

Begitu pula cara menghitung selisih $\mathrm{kWh}$ pada bulan Maret, April dan bulan Mei

2014, seperti terlihat pada tabel 10. di bawah ini

Tabel 10. Data Hasil perhitungan sebelum reconnecting

\begin{tabular}{|c|c|c|c|}
\hline Bular & $\begin{array}{c}\text { KWh Salur } \\
(\mathrm{KWh})\end{array}$ & $\begin{array}{c}\text { Selisih } \mathrm{kWh} \text { Sdur } \\
(\mathrm{kW})\end{array}$ & $\begin{array}{c}\text { Losses } \\
(\%)\end{array}$ \\
\hline Februari & 41220 & 707 & 1.72 \\
\hline Maret & 46170 & 1607 & 3.48 \\
A.ruil & 45575 & 1560 & 4.21 \\
\hline Mei & $443 / 4$ & 2165 & 4.48 \\
\hline
\end{tabular}

Dari hasil perhitungan selisish kWh Saluran dan besar losses tersebut maka dilakukan evaluasi dari penggunaan Tab connector dan terminal pada $\mathrm{kWh}$ meter. Dan data penggunaan connector di Gardu 079 Sovia sebelum Reconnecting SR dapat dilihat

\begin{tabular}{|c|c|c|c|c|c|}
\hline Bulir & $\begin{array}{l}\text { Jumlat: } \\
\text { Felar } 7 \text { gar. }\end{array}$ & $\begin{array}{c}\text { Jimilat } \\
\text { Teruinal } \\
\mathrm{k}^{\mathrm{kWh}}\end{array}$ & $\begin{array}{l}\text { Tumlah } \\
\text { Tab } \\
\text { Courstor }\end{array}$ & $\begin{array}{l}\text { Curnlat: } \\
\text { Cornetior }\end{array}$ & $\begin{array}{l}\text { Losics } \\
\text { Gartu }\end{array}$ \\
\hline $\begin{array}{c}\text { Desenstet } \\
\text { yin? }\end{array}$ & 145 & 270 & 1025 & 1296 & $13,73 \%$ \\
\hline $\begin{array}{c}\text { Jar:-ari } \\
20.4\end{array}$ & 105 & 20 & 1028 & $79 \%$ & $15, x<\%$ \\
\hline
\end{tabular}
pada Tabel di bawah ini

Tabel 11. Data Penggunaan Connector di Gardu 079 Sovia Sebelum Reconnecting Sambungan Rumah

Dengan tingginya losses yang terjadi dengan menggunakan Tab connector dan terminal $\mathrm{kWh}$, maka dilakukan reconnecting sambungan rumah. Reconnecting sambungan rumah ini merupakan penggantian seluruh connector yang terdapat pada sambungan rumah dengan tujuan untuk menekan losses yang terjadi pada connector. Jadi tab connector yang telah digunakan sebelumnya digantikan dengan menggunakan Compression Connector. Untuk terminal yang terdapat pada $\mathrm{kWh}$ meter digantikan dengan Joint Sleeve Bimetal. Setelah dilakukan pergantiang, maka kita dapatkan hasil pengukuran dari bulan Februari sampai Mei 2014 kita dapatkan terjadi pengurangan Losses pada gardu, seperti 
data yang ditampilkan pada tabel dibawah ini.

Tabel 12. Data Penggunaan Connector di Gardu 079 Sovia Setelah Reconnecting

\section{SR}

\begin{tabular}{|c|c|c|c|c|c|}
\hline Fiulian & $\begin{array}{c}\text { Jumilith } \\
\text { Pelinggan }\end{array}$ & $\begin{array}{l}\text { Tamlah } \\
\text {-utat Slizene } \\
\text { Biuelal }\end{array}$ & $\begin{array}{c}\text { Junt.h } \\
\cos \end{array}$ & $\begin{array}{l}\text { Jurulal. } \\
\text { Counetor }\end{array}$ & $\begin{array}{l}\text { Lusses } \\
\text { Garden }\end{array}$ \\
\hline $\begin{array}{c}\text { Fetruast } \\
2014\end{array}$ & 115 & $x 0$ & $10 \% x$ & 1296 & $1,2.2$ \\
\hline $\begin{array}{c}\text { Maret } \\
2014 \\
\end{array}$ & 115 & 370 & $102 x$ & 1796 & $2,48,4,2$ \\
\hline $\begin{array}{l}\text { Aynal } \\
2014\end{array}$ & 115 & 270 & 1025 & $12 \%$ & $1,21 \%$ \\
\hline $\begin{array}{l}\text { Xoei } \\
2014\end{array}$ & 112 & $2 ; 0$ & 1023 & $12 \%$ & $1,18 \%$ \\
\hline
\end{tabular}

Sumber : PT.PLN (Persero) Rayon Bukittinggi

Tabel 13 merupakan tabel dari hasil perhitungan untuk melihat perbandingan kinerja dari penggunaan tab connector dan terminal $\mathrm{kWh}$ meter dengan penggunaan CCO dan Joint Sleeve Bimetal. Dari tabel 13 dapat dilihat bahwa kinerja dari penggunaan CCO dan Joint Sleeve Bimetal lebih baik dari pada menggunakan $T a b$ Connector dan terminal $\mathrm{kWh}$ meter, karena losses dengan menggunakan CCO dan Joint Sleeve Bimetal lebih kecil dibandingkan dengan menggunakan tab connector dan terminal $\mathrm{kWh}$ meter. Ini terjadi karena, dengan menggunakan $\mathrm{CCO}$ dan Joint Sleeve Bimetal, loss kontak yang terjadi dapat di minimalisir, sehingga rugi-rugi yang terjadipun berkurang. Tabel 13. Data Hasil Perhitungan Losses Connector

\begin{tabular}{|c|c|c|c|c|c|}
\hline Bulan & $\begin{array}{l}\text { Loses } \\
\text { a }\end{array}$ & $\begin{array}{l}\text { Lossos } \\
\text { cormictos } \\
\text { (V) }\end{array}$ & $\begin{array}{l}\text { Bugi } \\
\text { Exy } \\
\text { Eular }\end{array}$ & 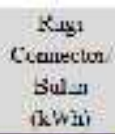 & Rcterargan \\
\hline Weseubet & 23.83 & 6.010' & & 4.51 & \multirow{2}{*}{$\begin{array}{l}\text { Zas coarsitor } \\
\text { dar terruiral }\end{array}$} \\
\hline Jeruari & 53.83 & $0.010 ?$ & $6+15$ & 4,95 & \\
\hline Thenasi & 172 & $6 \mathrm{ral} 3$ & 707 & 95 & \multirow{4}{*}{$\begin{array}{c}\text { COO } \\
\text { dar: Jomt sicove } \\
\text { Bimcts! }\end{array}$} \\
\hline Miat. & 3.45 & 0.0.1? & $100 !$ & 1.24 & \\
\hline sprit & +21 & 0.0032 & 1900 & 1.51 & \\
\hline i Nai & 415 & $1 / 2135$ & Xii) & 161 & \\
\hline
\end{tabular}

Setelah melakukan reconnecting SR diharapkan agar dapat menekan rugi $\mathrm{kWh}$ salur yang menyebabkan kerugian bagi pihak PLN. Berdasarkan hasil analisa yang kita lakukan didapatkan bahwa sebelum dilakukan reconnecting SR banyak terjadi loss kontak pada titik-titik sambungan. Loss kontak yang terjadi ini menyebabkan rugi $\mathrm{kWh}$ salur pada SR. Maka dari itu untuk mengurangi rugi pada $\mathrm{kWh}$ salur SR, kita lakukan reconnecting SR. Setelah dilakukan reconnecting SR kita dapatkan bahwa loss kontak pada pada gardu distribusi 079 sovia yang terjadi menurun dan rugi $\mathrm{kWh}$ salur juga berkurang, Hasil perhitungan rugi kWh Salur dapat dilihat pada tabel 14 di bawah ini

\section{Tabel 14. Data Hasil Perhitungan Rugi kWhSalur}

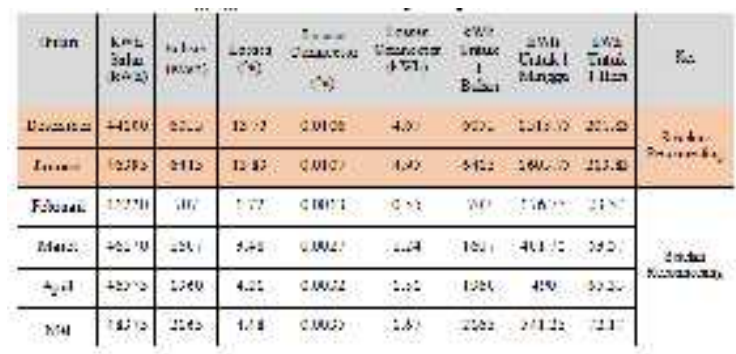

Setelah melakukan analisa sebelum reconnecting dan sesudah melakukan reconnecting kita dapatkan hasil yang sangat signifikan untuk mengurangi kerugian pada PT. PLN, Nah sekarang kita dapat menghitung dalam bentuk Rupiah rugi $\mathrm{kWh}$ setiap bulannya yang dialami oleh pihak PLN sebelum dilakukan reconnecting dan setelah dilakukan reconnecting, seperti pada tabel di bawah ini ;Tabel. 15 Rugi kWh Dalam Bentuk Rupiah

\begin{tabular}{|c|c|c|c|c|}
\hline Delea & I4 1 aai & 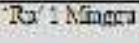 & Rol Brian & Beteserint \\
\hline Drsmil in & $3 f \div 71.398$ & $29: 286.618$ & Pg. $3.146-50$ & Iotetiar. \\
\hline Tanuas & $3 \mathrm{~F}+91.28$ & $\mathrm{e}_{\mathrm{n}} \cdot$ wh, 188 & $x+\langle x+y$ & Roxusutip \\
\hline Etrtem & $I_{f} \cdot 20,2: 2$ & $2 \mathrm{~g} .50,23 \mathrm{~s}$ & $\mathrm{Rp} .600 .559$ & \\
\hline Maret & T. $.45,5: 2$ & $20,91,39$ & $R 0.1, E S \subseteq 50$ & Setelin \\
\hline A.rril & $\mathrm{BF}] \mathrm{Y}, \mathrm{Kr}$ & $8 y+16$ sax & $P \eta 1$ ate $[0$, & Koxornsemg \\
\hline M. & I.p.6. $: 12$ & $2,150,062$ & Ro.1,646,259 & $\vdots$ \\
\hline
\end{tabular}

Dari tabel diatas dapat kita lihat bahwa sebelum melakukan reconnecting kerugian yang dialami pihak PLN cukup tinggi, setelah dilakukan perbaikan dengan melakukan reconnecting dapat menekan 
kerugian rugi-rugi jaringan dalam bentuk rupaih.

Dari tabel 14, yaitu tabel rugi $\mathrm{kWh}$ yang terjadi selama satu bulan, maka dapat dibuatkan grafik untuk melihat pengaruh reconnecting terhadap rugi $\mathrm{kWh}$ salur yang terjadi sebelum dan sesudah dilakukan reconnecting. Grafik rugi jaringan dapat dilihat pada grafik 1 berikut:

Grafik 1. Rugi kWh Salur

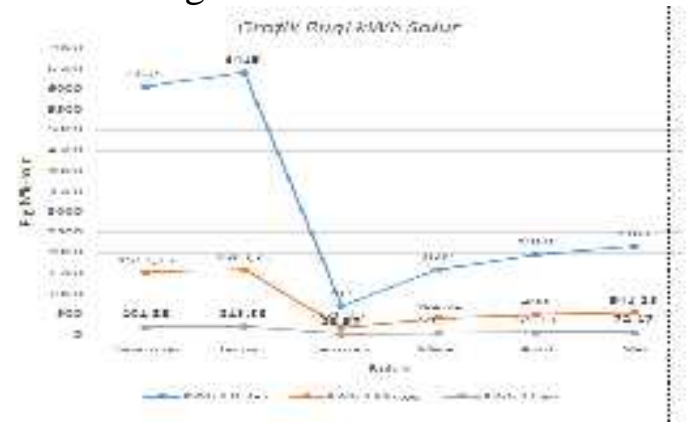

Selanjutnya dari tabel 15 yaitu tabel rugi $\mathrm{kWh}$ salur dalam bentuk rupiah setiap bulannya, maka dapat dibuatkan grafik untuk melihat rugi $\mathrm{kWh}$ salur dalam bentuk rupiah yang terjadi tiap bulannya. Dari grafik ini maka akan terlihat dengan jelas kerugian yang dialami oleh pihak PLN setiap bulannya. Grafiknya sebagai berikut:

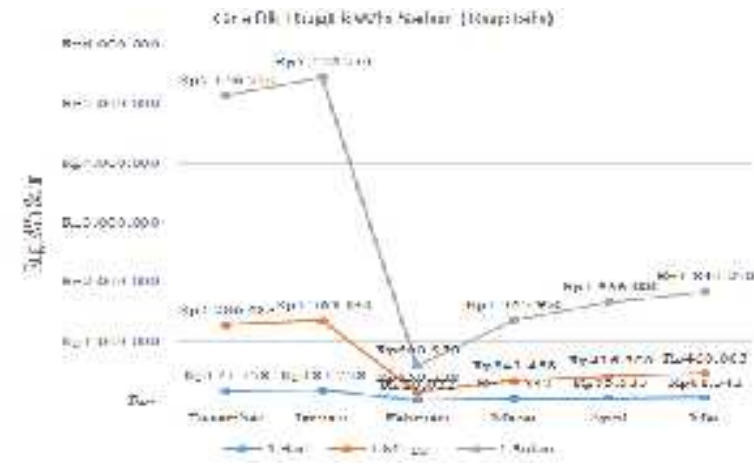

Analisa dengan Menggunakan metoda Jaringan Syaraf Tiruan untuk melihat kinerja reconnecting sambungan rumah sebelum dan sesudah pengerjaan. Maka didapatkan dari data hasil perhitungan yang terdapat pada Tabel 10, maka data tersebut digunakan untuk pemograman rugi jaringan sebelum dan sesudah melakukan reconnecting. Seperti pada tabel di bawah ini

\begin{tabular}{|c|c|c|}
\hline $\begin{array}{c}z_{1} \\
\text { (Bulaul) }\end{array}$ & $\begin{array}{c}X_{2} \\
\text { (Persentasi Rugi } \\
\text { Jarngan) }\end{array}$ & $\begin{array}{c}\mathrm{t} \\
\text { (Waku) }\end{array}$ \\
\hline Deseniber $201 I^{\prime} i(6)$ & 1373 & -1 \\
\hline$J_{\text {Anuari }} 2014$, 1 ; & 13.83 & -1 \\
\hline Feoruari $2014(2)$ & 1.72 & -1 \\
\hline Maret 2014 (3) & 3.18 & 1 \\
\hline April 2014 (4) & 4.21 & 1 \\
\hline Mei2014(5) & 4.43 & 1 \\
\hline
\end{tabular}

Setelah menentukan dan menginput data vector masukan dan target seperti tabel 16 ke aplikasi Matlab, maka akan didapatkan hasil pemrograman untuk melihat kinerja rugi jaringan sebelum dan sesudah dilakukan reconnecting.

Grafik 3. sebelum dilakukan reconnecting SR

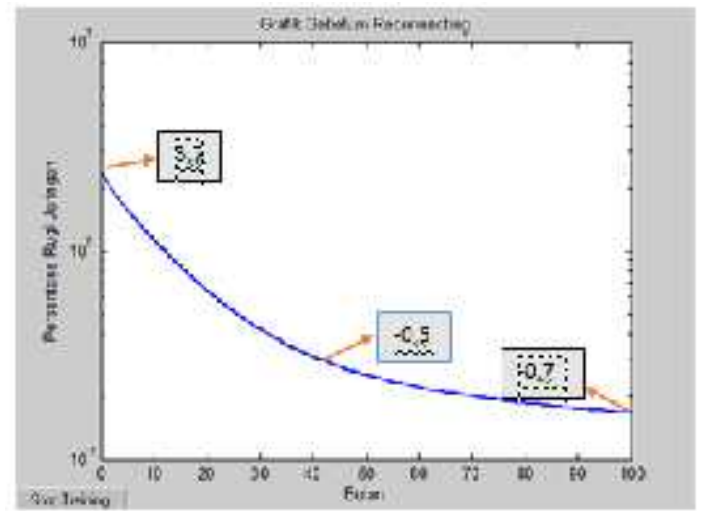

Grafik 4 Setelah dilakukan reconnecting SR

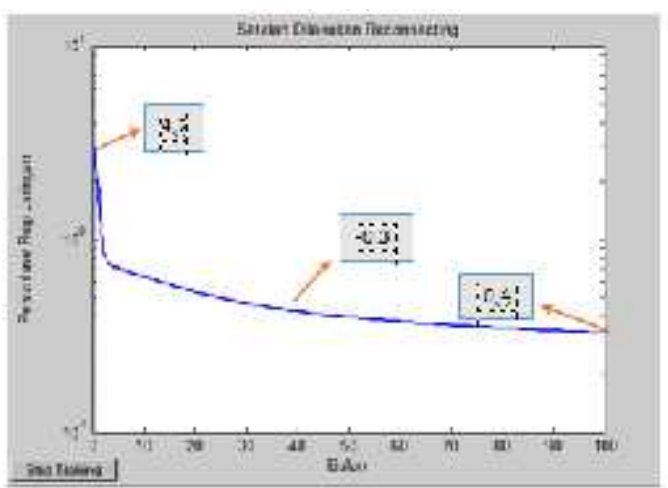

Pada grafik 3, yaitu grafik sebelum dilakukan reconnecting dapat dilihat bahwa 
untuk proses pembelajaran dimulai pada titik 3,7. Dari proses pembelajaran sampai ke proses mengenal atau mengerti berjalan cukup lama yaitu selama 40 kali percobaan dan berhenti pada titik -0,5. Setelah proses mengenal atau mengerti, maka proses selanjutnya yaitu berhenti mempelajari atau sampai data stabil. Peroses berhenti pembelajaran ini berada pada titik $-0,7$.

Pada grafik 4, yaitu grafik setelah dilakukan reconnecting dapat dilihat bahwa untuk proses pembelajaran dimulai pada titik 4,7. Dari proses pembelajaran sampai ke proses mengengal atau mengerti berjalan sangat cepat yaitu 3 kali percobaan dan berhenti pada titik $-0,12$. Untuk proses mengena stabil pada titik -0.3 setelah melakukan 40 kali percobaan. Setelah proses mengenal atau mengerti, maka proses selanjutnya yaitu berhenti mempelajari atau sampai data stabil. Peroses berhenti pembelajaran ini berada pada titik $-0,4$.

Jadi dari kedua grafik dapat dilihat bahwa pada grafik kedua kinerja rugi $\mathrm{kWh}$ salur lebih baik dari pada grafik pertama. Berarti disini hasil prediksi dari jaringan syaraf tiruan sesuai dengan data perhitungan manual. Bahwa dengan melakukan reconnecting sambungan rumah (SR) dapat menekan rugi $\mathrm{kWh}$ salur.

\section{KESIMPULAN}

Berdasarkan penelitian yang dilakukan tentang reconnecting sambungan rumah (SR) untuk menekan rugi jaringan, maka dapat di ambil kesimpulan sebagai berikut:

1. Reconnecting sambungan rumah (SR) merupakan penggantian tab connector dengan compression connector dengan tujuan untuk menekan rugi $\mathrm{kWh}$ salur.

2. Rugi Kwh salur sebelum dilakukan reconnecting yaitu sebesar 13,83\%pada bulan Januari, jika dirupiahkan sebesar Rp. 5.452.750.
3. Rugi Kwh salur setelah dilakukan reconnecting yaitu sebesar 4,48\% padabulan Mei, jika dirupiahkan sebesarRp. 1.840.250.

4. Dari hasil kinerja reconnecting SR ini dianjurkan untuk melakukan reconnecting, karena dapat menekan rugi KWh salur yang mana sebelum dilakukan reconnecting rugi $\mathrm{kWh}$ salur sebesar 13,83 \% (6055 kWh), setelah dilakukan reconnecting rugi $\mathrm{kWh}$ salur di tekan menjadi 4,48\% (2165 kWh).

5. Dengan menggunakan metoda jaringan syaraf tiruan, dapat memudahkan dalam mengklasifikasikan rugi $\mathrm{kWh}$ saluran sebelum melakukan reconnecting SR dan sesudah melakukan reconnecting SR dalam memperbaiki rugi $\mathrm{kWh}$ yang terjadi.

\section{DAFTAR PUSTAKA}

[1]Agustin Maria. 2012. "Penggunaan Jaringan Syaraf Tiruan Backpropagation untuk Seleksi Penerimaan Mahasiswa Baru pada Jurusan Teknik Komputer di Politeknik Negeri Sriwijaya". Tesis. Semarang: Universitas Diponegoro.

[2] Direksi PT. PLN (Persero). 2010, Buku 2 Standar Konstruksi Sambungan Tenaga Listrik, Jakarta : PT. PLN (Persero).

[3] Direksi PT. PLN (Persero). 2010, Buku 3 Standar Konstruksi Jaringan Tegangan Rendah Tenaga Listrik, Jakarta : PT. PLN (Persero).

[4] PT.SinarindoWiranusaElektrik. 2008. Pole Hardware \& Cable Accessories, (Online), (http://www.sinarindo.com/ccs.htm, diakses 27 agustus 2014).

[5] Siang, Jong Jek. 2009. Jaringan Syaraf Tiruan dan Pemrogramannya Menggunnakan Matlab. Yogyakarta: Andi. 